Review Article

\title{
Over-the-scope clip
}

\author{
Bhanwar Singh Dhandhu, Kumar Shwetanshu Narayan, Surinder Sultania, Sandeep Nijhawan
}

Department of Gastroenterology, SMS Medical College and Hospital, Jaipur, Rajasthan, India

Abstract
$\begin{aligned} & \text { The endoscopic clips were first described by Hayashi in Japan in 1975. Since then, many } \\ & \text { different types of clips have been introduced to the gastroenterology practice. Over-the-scope } \\ & \text { clip (OTSC) or the "beer claw" was introduced in the year 2010. It works on the principle } \\ & \text { of dynamic compression and is applied over the scope like a band ligator. OTSC is a new } \\ & \text { endoscopic modality which can be used in acute gastrointestinal hemorrhage, iatrogenic } \\ & \text { perforation, anastomotic leak, and chronic fistula treatment with fairly good success rate } \\ & \text { and therefore, is now being considered as an alternative to surgery, especially in situations } \\ & \text { where surgery is not feasible. }\end{aligned}$
Key words

\section{Introduction}

The endoscopic clips were first described by Hayashi in Japan in 1975. ${ }^{[1]}$ After improvement in the design, it was used by Soehendra in patients of upper gastrointestinal (GI) bleeding for hemostasis. ${ }^{[2]}$ Later on, these clips were improved as reloadable, preloaded quick clip, and rotatable clip. A new type of clip was introduced in the year 2010, working on a different principle as compared to the previous clips which were through-the-scope (TTS); this clip was over the scope before deployment loaded on a cylinder. The deployment was similar to band ligation, was named as over-the-scope clip (OTSC), and was commonly known as the "bear claw."

\section{Over-the-scope Clip Device}

The device consists of a preloaded cylinder with the clip and thread, a thread retriever, and the release hand wheel [Figure 1]. ${ }^{[3]}$ The clip is made up of nitinol alloy, which allows a high grade of elasticity ${ }^{[4]}$ and comes in three

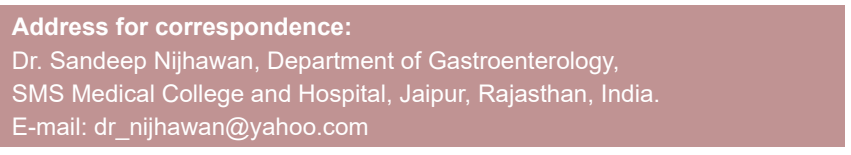

\begin{tabular}{|l|c|}
\hline \multicolumn{2}{|c|}{ Access this article online } \\
\hline \multirow{2}{*}{$\begin{array}{l}\text { Website: } \\
\text { www.jdeonline.in }\end{array}$} & Quick Response Code \\
\hline DOI: & \\
10.4103/0976-5042.189127 & D. \\
\hline
\end{tabular}

different types: Type "a" (rounded) is with blunt spikes and meant for compression effect particularly in the thinner walled esophagus and colon, Type " $t$ " (pointed) has teeth with small spikes which not only compresses the tissue but also has better anchoring, and the third Type "gc" (longer pointed) has elongated teeth with spikes, which is specific for closure of the stomach wall which has maximum thickness as compared to duodenum and colon.

The applicator cap, with a mounted nitinol clip, is affixed to the tip of the endoscope in a manner similar to that of a variceal band ligation cap. The clip fits onto the cylindrical cap in the open position. Caps are available in three diameters to accommodate various endoscope diameters: (1) $11 \mathrm{~mm}$ (designed for endoscope diameters $8.5-11 \mathrm{~mm}$ ), (2) $12 \mathrm{~mm}$ (for endoscope diameters $10.5-12 \mathrm{~mm}$ ), and (3) $14 \mathrm{~mm}$ (for endoscope diameters $11.5-14 \mathrm{~mm}$ ). With the applicator cap attached to the endoscope, the corresponding outer diameter of the instrument is $16.5,17.5$, or $21 \mathrm{~mm}$, respectively. Caps are also available in two depths ( 3 and $6 \mathrm{~mm}$ ) to allow variation in the amount of tissue grasped during approximation. The commonly used depth is of $6 \mathrm{~mm}$ which has adequate depth for retrieval of the tissue in the cylinder for better deployment of the clip.

This is an open access article distributed under the terms of the Creative Commons Attribution-NonCommercial-ShareAlike 3.0 License, which allows others to remix, tweak, and build upon the work non-commercially, as long as the author is credited and the new creations are licensed under the identical terms.

For reprints contact: reprints@medknow.com

How to cite this article: Dhandhu BS, Narayan KS, Sultania S, Nijhawan S. Over-the-scope clip. J Dig Endosc 2016;7:47-50. 


\section{Assist devices}

There are three additional instruments available that facilitate the use of OTSC.

\section{Twin grasper}

This device has two separate, lateral, independently controlled, mobile jaws [Figure 1] ${ }^{[3]}$ which help in approximating the wound edges before deploying the clip. It is particularly useful for larger defects and chronic defects associated with indurated tissue where suction alone may be inadequate to approximate tissue. It is available in flexible catheter length of 165 and $220 \mathrm{~cm}$ for use with gastroscope and colonoscope, respectively. An endoscope working channel of at least $3.2 \mathrm{~mm}$ is required to use this device with the OTSC system. The approximated tissue is then pulled into the applicator cap; additional suction is applied if necessary, and the clip is then deployed by turning the hand wheel.

\section{Anchor}

This device is used to retract hard and fibrotic tissue into the cap when simple suction or the twin grasper may not be effective. This accessory consists of a $165 \mathrm{~cm}$ long flexible catheter with three retractable needle pins [Figure 1]. ${ }^{[3]}$ On releasing, the three pins pierce tissue along a curved path, thereby anchoring it. The tissue can then be pulled into the applicator cap, suction is applied if necessary, and the clip is deployed. The anchor is then retracted and removed. An endoscope working channel of at least $3.2 \mathrm{~mm}$ is required to use this device with the OTSC system.

\section{Reloader}

After deployment of the initial clip, this device [Figure 1] ${ }^{[3]}$ assists in mounting additional clips onto the applicator cap. This device is useful if more than 1 clip is to be placed in the same treatment session.

\section{Functional principle}

The OTSC works on the principle of dynamic compression that it compresses the tissue in between its teeth and the space between the teeth allows microperfusion of the clipped tissue. Therefore, there is no necrosis of the clipped tissue. The clip

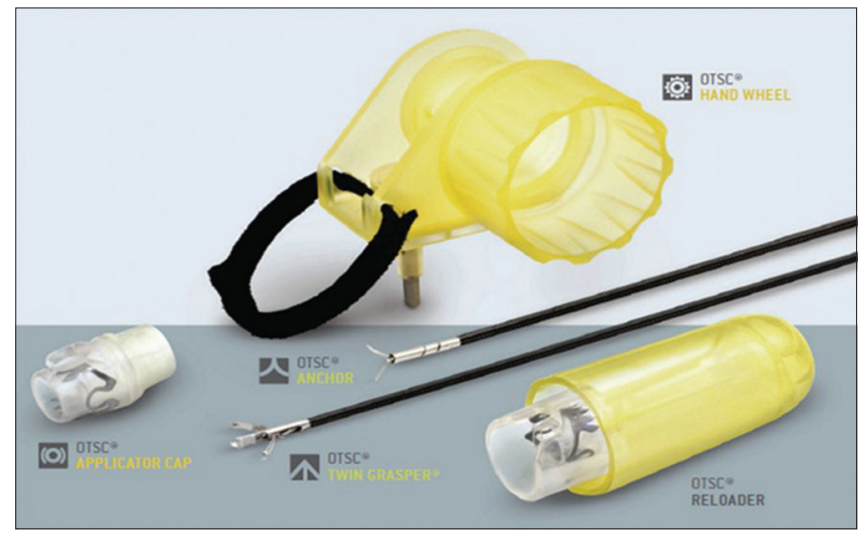

Figure 1: The OTSC system ${ }^{[3]}$ enables a dynamic closure of the tissue avoiding inadequate closure overtime which usually occurs in fixed suture loops. ${ }^{[4,5]}$

\section{Procedure}

The clip cylinder is fixed on the tip of the endoscope until the stopper in the cap, if it is not done up to the stopper, it could slide forward when turning the hand wheel which may lead to clipping of the instrument. In case there is failure to do so, the cap should be reapplied till the stopper in the cap under the endoscopic view.

First, the bleeding source should be identified by diagnostic endoscopy, followed by application of the cap with the clip over the tip of the endoscope. The thread is retrieved by the retriever through the suction channel and fixed to the release handle wheel. The bleeding site is identified and sucked into the cap, followed by release of the clip by rotating the release wheel. In patients who develop iatrogenic perforation of the bowel, twin grasper is used to grasp the two edges and the retraction of the tissue in the cap is followed by release of clip and withdrawal of the twin grasper. Patients of chronic inflammatory fistula have fibrosis along with inflammation making it difficult to suck or grasp; therefore, the anchor is required, which not only anchor the tissue but also guide the cap to the lesion which is then retrieved into the cap followed by release of the clip and withdrawal of the anchor.

\section{Discussion}

OTSC is a new endoscopic modality which has proven to be safe and effective treatment in patients with GI bleed, perforations, anastomotic leaks, and chronic GI fistulae. In patients presenting with GI bleed who have relapsed after conventional treatment, OTSC has been found to be technically successful in $100 \%$ and clinically successful in $94-100 \%$ cases [Table 1]. ${ }^{[6-11,21]}$ In patients with iatrogenic perforation and anastomotic leaks, overall technical success of OTSC is $85-100 \%$ and clinical success is $80-100 \%$ [Table 2]. ${ }^{[6-9,12-18,21]}$ Patients with chronic fistula have fibrosis with chronic inflammation. The technical success in such patients is $75-100 \%$ and clinical success is $75-100 \%$ [Table 3]. ${ }^{[6,7,12,14-16,21]}$

With respect to Indian literature on OTSCs, a recent prospective trial by Goenka et al. has shown a technical and

Table 1: Studies showing success rates of over-the-scope clip in gastrointestinal hemorrhage

\begin{tabular}{lccc}
\hline Author & $\begin{array}{c}\text { Number } \\
\text { of lesions }\end{array}$ & $\begin{array}{c}\text { Technical } \\
\text { success }(\%)\end{array}$ & $\begin{array}{c}\text { Clinical } \\
\text { success (\%) }\end{array}$ \\
\hline Albert et al..$^{[6]}$ & 7 & $100(7 / 7)$ & $57(4 / 7)$ \\
Baron et al..$^{[7]}$ & 7 & $100(7 / 7)$ & $100(7 / 7)$ \\
Kirschniak et al..$^{[8]}$ & 7 & $100(7 / 7)$ & $100(7 / 7)$ \\
Kirschniak et al..$^{[9]}$ & 27 & $100(27 / 27)$ & $100(27 / 27)$ \\
Repici et al..$^{[11]}$ & 7 & $100(7 / 7)$ & $100(7 / 7)$ \\
Manta et al. ${ }^{[10]}$ & 30 & $100(30 / 30)$ & $97(27 / 30)$ \\
Goenka et al..$^{[21]}$ & 6 & $100(6 / 6)$ & $100(6 / 6)$ \\
\hline
\end{tabular}




\begin{tabular}{|c|c|c|c|}
\hline Author & $\begin{array}{l}\text { Number } \\
\text { of lesions }\end{array}$ & $\begin{array}{c}\text { Technical } \\
\text { success (\%) }\end{array}$ & $\begin{array}{c}\text { Clinical } \\
\text { success }(\%\end{array}$ \\
\hline Albert et al. ${ }^{[6]}$ & 5 & $80(4 / 5)$ & $80(4 / 5)$ \\
\hline Arezzo et al. ${ }^{[12]}$ & 8 & $87(7 / 8)$ & $87(7 / 8)$ \\
\hline Baron et al. ${ }^{[7]}$ & 8 & NA & $62(5 / 8)$ \\
\hline $\begin{array}{l}\text { Gubler and } \\
\text { Bauerfeind }^{[13]}\end{array}$ & 14 & $93(13 / 14)$ & $78(11 / 14)$ \\
\hline Kirschniak et al. ${ }^{[8]}$ & 4 & $100(4 / 4)$ & $100(4 / 4)$ \\
\hline Kirschniak et al. ${ }^{[9]}$ & 11 & $100(11 / 11)$ & $100(11 / 11)$ \\
\hline Manta et al..$^{[14]}$ & 5 & $100(5 / 5)$ & $80(4 / 5)$ \\
\hline Parodi et al. ${ }^{[15]}$ & 6 & $88(5 / 6)$ & $83(5 / 6)$ \\
\hline Sandman et al. ${ }^{[16]}$ & 7 & NA & $86(6 / 7)$ \\
\hline Voermans et al. ${ }^{[18]}$ & 36 & $92(33 / 36)$ & $89(32 / 36)$ \\
\hline Seebach et al..$^{[17]}$ & 7 & $85(6 / 7)$ & $57(4 / 7)$ \\
\hline Goenka et al. ${ }^{[21]}$ & 3 & $100(3 / 3)$ & $100(3 / 3)$ \\
\hline
\end{tabular}

$\mathrm{NA}=$ Not available

Table 3: Studies showing success rates of over-the-scope clip in chronic gastrointestinal lesions (fistulae)

\begin{tabular}{lccc}
\hline Author & $\begin{array}{c}\text { Number } \\
\text { of lesions }\end{array}$ & $\begin{array}{c}\text { Technical } \\
\text { success }(\%)\end{array}$ & $\begin{array}{c}\text { Clinical } \\
\text { success }(\%)\end{array}$ \\
\hline Albert et al..$^{[6]}$ & 7 & $100(7 / 7)$ & $71(5 / 7)$ \\
Arezzo et al..$^{[12]}$ & 6 & $83(5 / 6)$ & $83(5 / 6)$ \\
Baron et al..$^{[7]}$ & 28 & $\mathrm{NA}$ & $71(20 / 28)$ \\
Manta et al..$^{[14]}$ & 9 & $88(8 / 9)$ & $88(8 / 9)$ \\
Parodi et al. ${ }^{[15]}$ & 4 & $100(4 / 4)$ & $100(4 / 4)$ \\
Sandman et al. ${ }^{[16]}$ & 6 & $\mathrm{NA}$ & $83(5 / 6)$ \\
Goenka et al..$^{[2]}$ & 4 & $75(3 / 4)$ & $75(3 / 4)$ \\
\hline
\end{tabular}

clinical success rate of $100 \%$ and $83.3 \%$ in GI hemorrhage and GI defects, respectively. This study also highlighted the fact that tattooing to mark the leak site can help in accurate deployment and thus increase the success rate of OTSCs. ${ }^{[21]}$

OTSC comprises newer generation clips which have several advantages with respect to TTS clips. Due to its large size and the use of the cap and tissue graspers (forceps or anchor), the OTSC system allows for the entrapment of a larger amount of tissue and provides high stability and closure and minimal strain on surrounding tissue, thereby preventing ischemia or cutting the tissue. The OTSCs is designed to create a full-thickness closure of perforations, whereas a TTS clip can compress only a limited amount of tissue. Accordingly, the hemostatic effect of OTSC is more in comparison with TTS clips. The clinical success also appears to be better than TTS clips in the closure of iatrogenic perforations, and the average number of OTSC clip required is much less than the TTS clips. ${ }^{[18]}$ While TTS clips are effective for leaks smaller than $10 \mathrm{~mm}$, OTSC are preferred for larger defects $(20-30 \mathrm{~mm}){ }^{[19]}$ However, if reloading of clips is required, OTSC require removal of endoscope whereas TTS clips do not. Another disadvantage is that OTSC are of large diameter and therefore utmost care has to be taken while introducing them through physiologically narrow spaces such as cricopharynx or the pylorus. There are case reports of iatrogenic perforations with OTSCs which are rare with TTS clip. ${ }^{[18]}$

As far as limitations of OTSC are concerned, studies have shown that OTSCs are not suitable for the closure of chronic lesions with hard, severely fibrotic wounds because it is difficult to draw such a lesion into the top of the device. In addition, the OTSCs are also not recommended for defects larger than $30 \mathrm{~mm} .{ }^{[20]}$

\section{Conclusion}

The OTSC clip is a new endoscopic treatment for acute GI hemorrhage, iatrogenic perforation, anastomotic leak, and chronic fistula with fair technical and clinical success rate and may be a good alternative to surgery, especially in situations where surgery is not feasible.

\section{Financial support and sponsorship}

Nil.

\section{Conflicts of interest}

There are no conflicts of interest.

\section{References}

1. Hayashi I, Yonezawa TM, Kuwabara T, Kudoh I. The study on staunch clip for the treatment by endoscopy. Gastrointest Endosc 1975;17:92-101.

2. Binmoeller KF, Thonke F, Soehendra N. Endoscopic hemoclip treatment for gastrointestinal bleeding. Endoscopy 1993;25:167-70.

3. Kouklakis G, Zezos P, Liratzopoulos N, Gatopoulou A, Oikonomou A, Pitiakoudis M, et al. Endoscopic treatment of a gastrocutaneous fistula using the over-the-scope-clip system: A case report. Diagn Ther Endosc 2011;2011:384143.

4. von Renteln D, Denzer UW, Schachschal G, Anders M, Groth S, Rösch T. Endoscopic closure of GI fistulae by using an over-the-scope clip (with videos). Gastrointest Endosc 2010;72:1289-96.

5. Raju GS, Gajula L. Endoclips for GI endoscopy. Gastrointest Endosc 2004;59:267-79

6. Albert JG, Friedrich-Rust M, Woeste G, Strey C, Bechstein WO, Zeuzem $S$, et al. Benefit of a clipping device in use in intestinal bleeding and intestinal leakage. Gastrointest Endosc 2011;74:389-97.

7. Baron TH, Song LM, Ross A, Tokar JL, Irani S, Kozarek RA. Use of an over-the-scope clipping device: Multicenter retrospective results of the first U.S. experience (with videos). Gastrointest Endosc 2012;76:202-8.

8. Kirschniak A, Kratt T, Stüker D, Braun A, Schurr MO, Königsrainer A. A new endoscopic over-the-scope clip system for treatment of lesions and bleeding in the GI tract: First clinical experiences. Gastrointest Endosc 2007;66:162-7.

9. Kirschniak A, Subotova N, Zieker D, Königsrainer A, Kratt T. The over-the-scope clip (OTSC) for the treatment of gastrointestinal bleeding, perforations, and fistulas. Surg Endosc 2011;25:2901-5.

10. Manta R, Galloro G, Mangiavillano B, Conigliaro R, Pasquale L, Arezzo A, et al. Over-the-scope clip (OTSC) represents an effective endoscopic treatment for acute GI bleeding after failure of conventional techniques. Surg Endosc 2013;27:3162-4.

11. Repici A, Arezzo A, De Caro G, Morino M, Pagano N, Rando G, et al. Clinical experience with a new endoscopic over-the-scope clip system for use in the GI tract. Dig Liver Dis 2009;41:406-10.

12. Arezzo A, Verra M, Reddavid R, Cravero F, Bonino MA, Morino M. Efficacy of the over-the-scope clip (OTSC) for treatment of colorectal postsurgical leaks and fistulas. Surg Endosc 2012;26:3330-3. 
13. Gubler C, Bauerfeind P. Endoscopic closure of iatrogenic gastrointestinal tract perforations with the over-the-scope clip. Digestion 2012;85:302-7.

14. Manta R, Manno M, Bertani H, Barbera C, Pigò F, Mirante V, et al. Endoscopic treatment of gastrointestinal fistulas using an over-the-scope clip (OTSC) device: Case series from a tertiary referral center. Endoscopy 2011;43:545-8.

15. Parodi A, Repici A, Pedroni A, Blanchi S, Conio M. Endoscopic management of GI perforations with a new over-the-scope clip device (with videos). Gastrointest Endosc 2010;72:881-6.

16. Sandmann M, Heike M, Faehndrich M. Application of the OTSC system for the closure of fistulas, anastomosal leakages and perforations within the gastrointestinal tract. Z Gastroenterol 2011;49:981-5.

17. Seebach L, Bauerfeind P, Gubler C. "Sparing the surgeon": Clinical experience with over-the-scope clips for gastrointestinal perforation.
Endoscopy 2010;42:1108-11.

18. Voermans RP, Le Moine O, von Renteln D, Ponchon T, Giovannini $\mathrm{M}$, Bruno $\mathrm{M}$, et al. Efficacy of endoscopic closure of acute perforations of the gastrointestinal tract. Clin Gastroenterol Hepatol 2012;10:603-8

19. Qadeer MA, Dumot JA, Vargo JJ, Lopez AR, Rice TW. Endoscopic clips for closing esophageal perforations: Case report and pooled analysis. Gastrointest Endosc 2007;66:605-11.

20. Nishiyama N, Mori H, Kobara H, Rafiq K, Fujihara S, Kobayashi M, et al. Efficacy and safety of over-the-scope clip: Including complications after endoscopic submucosal dissection. World J Gastroenterol 2013;19:2752-60.

21. Goenka MK, Rai VK, Goenka U, Tiwary IK. Endoscopic management of gastrointestinal leaks and bleeding with the over-the-scope clip: A prospective study. Clin Endosc 2016. [Epub ahead of print]. 